\title{
Effects of topical and dietary use of shea butter on animals
}

\author{
Malachi Oluwaseyi Israel \\ Department of Biochemistry, Ekiti State University, Ado-Ekiti, Nigeria
}

Email address:

malachiseyi@gmail.com

\section{To cite this article:}

Malachi Oluwaseyi Israel. Effects of Topical and Dietary Use of Shea Butter on Animals. American Journal of Life Sciences. Vol. 2, No. 5, 2014, pp. 303-307. doi: 10.11648/j.ajls.20140205.18

\begin{abstract}
Shea butter is the fat extracted from the nut of Africa Shea tree (Vitellaria paradoxa). It is used in cosmetic formulations and as a substitute for Cocoa butter in chocolate industries. It is edible and used cooking fat in Africa. The saponifiable fraction of Shea butter is composed primarily of stearic and oleic acids with lesser amounts of palmitic, linoleic and arachidic acids while the unsaponifiable fraction of Shea butter is composed of bioactive substances that are responsible for Shea butter's medicinal properties. Shea butter is a solid at room temperature and melts at body temperature. It is therefore useful for skin care as it has sun screening properties and acts as an emollient and skin moisturizer. Topical use of Shea butter has also demonstrated anti-aging and anti-inflammatory properties. Dietary intake of Shea butter has hypocholesterolemic effect and reduces serum and organ protein concentrations.
\end{abstract}

Keywords: Shea Butter, Skin, Allergy, Inflammation, Cholesterol

\section{Introduction}

Shea butter is an off-white or ivory-coloured fat extracted from the nut of African Shea tree (Vitellaria paradoxa formerly Butryspermum paradoxum, B.parkii and B. paradoxa) [1] Shea tree grows naturally in the wild of the dry savanna belt of West Africa, from Senegal in the West to Sudan in the East and onto the foot hills of the Ethiopian mountains [2-4]. The West African trees are classified as the subspecies "paradoxa" and the East African one as "nilotica" [5-7]. It is considered a sacred tree by many communities and ethnic groups and plays important roles in religious and cultural ceremonies where is also believed to have some spiritual protective powers $[8,9]$. It has been claimed to possess potentials to improve nutrition, boost food supply in the annual hungry season [10], foster rural development, and support sustainable land care [11]. Different parts of the plant including leaves, roots, seeds, fruit and stem bark have been used in the treatment of enteric infections such as diarrhea, dysentery, helminthes and other gastrointestinal tract infections, skin diseases and wound infections [12]. The bark is used to suppress cough and also to treat leprosy [13]. Shea nut contains about $60 \%$ fat (Shea butter) [14], and together with the oil palm serve as sources of edible oil for many households in many parts of the Sahel Africa, particularly Northern Nigeria [3,11,15-18].

Shea butter is renowned for its use as a component of cosmetic formulations $[16,19]$ and as a substitute for Cocoa butter in chocolate industries [20], although the taste is noticeably different [21]. Shea butter is used by local healers as a treatment for rheumatism, inflammation of the nostrils, nasal congestion, leprosy, cough, and minor bone dislocation [22-25]. It is also used as raw material for the production margarine, soap, detergent and candle [26]. Low quality butter and by-products of processed nuts are smeared on earthen walls of houses as a waterproof to protect walls during the rainy season [27]. Shea butter has also been used for soothing and accelerating healing after circumcision, and for preventing stretch marks in African pregnant women and as an insect repellent, providing protection against Simulium infection [24]. There are no reports of allergic reaction owing to consumption of Shea butter or its produce $[28,29]$. The United States Agency for International Development, Gassel Consulting, and many other companies have suggested a classification system for Shea butter separating it into five grades: A (raw or unrefined, extracted using water), B (refined), C (highly refined and extracted with solvents such as hexane), D (lowest uncontaminated grade), E (with contaminants) [30]. Large quantities of Shea butter are produced in West Africa though the exact production figures are not known [31]. This work reviews the effects of topical and dietary use of Shea butter on animal system. 


\section{Chemical Composition of Shea Butter}

In addition to a stearic and oleic acids rich saponifiable fraction, Shea butter contains an unsaponifiable fraction composed of bioactive substances that are responsible for Shea butter's medicinal properties [32]. With regional variation in concentrations $[6,33]$, the unsaponifiable fraction of Shea butter is composed primarily of triterpene alcohols, with some hydrocarbons, sterols, and other minor components such as vitamin E [34-36]. The saponifiable triglyceride fraction of Shea butter constitutes about $90 \%$ by mass of the butter [34-38] and is composed primarily of stearic and oleic acids with lesser amounts of palmitic, linoleic and arachidic acids [39]. The triacylglyceride fraction is made up of fatty acids (acyl chains) attached to a glycerol backbone [40]. Since different fatty acids are present in Shea butter, different combinations of fatty acids attached to the glycerol are possible. In Shea butter, the most predominant combination is SOS (S-Stearic, O-oleic) making up to $40 \%$ of the total triacylglycerol molecules, followed by SOO (27\%), POS (P-palmitic, 6\%) and POP (1\%) [36]. Di Vincenzo and co-workers [6] however concluded that SOO, OOO, and SOS were the major triglycerides in Shea butter with regional variation. Shea butter contains relatively high amount of saturated fatty acids compared to other plant-sourced lipids including: grape seed oil (total saturated fatty acids: 10.4-14.3\% of total fatty acids), olive oil (12.7-16.2 \%), and canola oil (5.5-7.7 \%) which are all, in contrast to Shea butter, liquid at room temperature and have saturated fatty acids less than $20 \%$ of total fatty acids [41-43]. Shea butter fatty acid composition has been found to vary across the African countries [6,44]. Maranz and co-workers [44], as shown in Table 1, nevertheless presented ranges and mean values of the fatty acid compositions.

Table 1. Fatty Acid profile of Shea Butter

\begin{tabular}{llll}
\hline Fatty Acids & Mean (\%) & Min (\%) & Max (\%) \\
\hline Palmitic (16:0) & 4.0 & 2.6 & 8.4 \\
Stearic (18:0) & 41.5 & 25.6 & 50.2 \\
Oleic (18:1) & 46.4 & 37.1 & 62.1 \\
Linoleic (18:2) & 6.6 & 0.6 & 10.8 \\
Arachidic(20:0) & 1.3 & 0.0 & 3.5 \\
\hline
\end{tabular}

\section{Effects of Shea Butter}

Sun-screening function: Sun-screens absorb or reflect some of the sun's ultraviolet (UV) radiation reaching the skin exposed to sunlight and thus helps protect against sunburn, preventing erythema and reducing further risk of sun-induced skin-cancer. The major cause of photocarcinogenesis is UVB radiation $(290-320 \mathrm{~nm})$ since it directly interacts with cellular DNA, forming cyclobutane pyrimidine dimers and thymine glycols [45]. Cinnamate esters of triterpene alcohol which are the main constituent of Shea butter's unsaponifiable fraction are known to have strong absorbance of UV radiation in the wavelength range at $250-300 \mathrm{~nm}$, which make the addition of Shea butter's unsaponifiables into sunscreens provide synergistic sun-protection by increasing absorption of UVB radiation [46]. However, the effectiveness of the triterpenes is somewhat doubted since studies using double-fractionated Shea butter with $20 \%$ of triterpene esters found that this triterpenic fraction only provided the sun protection factor (SPF) of 3-4 [36,47].

As an emollient and skin moisturizer: Due to its semi-solid characteristics and buttery consistency, Shea butter is great emollient and moisturizer for the skin, scalp and hair even without further processing [46]. However Shea butter is usually found as active component of processed moisturizers [48]. In addition, fractionated Shea butter especially olein fraction is easily formulated in creams or surfactant based products such as bath products and shampoo to provide the skin, scalp, and hair with well-maintained or increased moisture $[36,46,49]$. Shea butter melts at body temperature, acts as a "refatting" agent, has good water-binding properties and absorbs rapidly into the skin; making it useful for skin care [50]. In an article titled 'Winter Itch', Shea butter was recommended for repairing dry inflamed skin caused by dermatitis and as a night time moisturizer for hands and feet [51]. Also, in a study by Poelman and co workers [52], a cream containing $5 \%$ Shea Butter versus a placebo cream were applied to the forearms of 10 volunteers. Short-term moisturization was observed; it peaked after 1 hour and persists for 8 hours. For all subjects, a daily application maintains a very good moisturization of the superficial layers of the skin. Shea butter has also been shown to be superior to mineral oil at preventing transepidermal water loss (TEWL). In a test where participants' arms were washed in ethanol, it was found that Shea butter was able to help the skin totally recover from TEWL within two hours [53]. One study showed that it worked as an emollient for eczema. Using a scale from zero to five - zero denoting clear and five denoting very severe disease - Shea butter took a three down to a one, while Vaseline only took a three down to a two [54].

Anti-aging properties: It has been revealed that Shea butter has UV anti-erythemic activity, which helps tissue cell regeneration and softening of the skin [55]. In a clinical study involving 30 volunteers, Renard [56] reported that Shea butter diminished various aging signs. In another clinical study by the same author for studying dry, delicate or aging skin, 49 volunteers applied twice a day either $15 \%$ or pure Shea Butter and discovered that Shea butter prevented photo-aging. Also, in a study with rats, Shea butter was shown to boost collagen production [57]. Collagen and elastin are the major structural proteins providing skin with toughness and plumpness and $\alpha$-amyrin and lupeol, the triterpenes found in the unsaponifiable fraction of Shea butter, were found to contribute to the inactivation of proteases such as metalloprotease (e.g., collagenase) as well as serine protease (e.g., elastase) [36]. The anti-aging, potentially collagen-boosting effects were attributed to its unsaponifiable components $[32,36]$.

Anti-inflammatory properties: The anti-inflammatory effects of Shea butter have been demonstrated through inhibition of Inos, Cox-2, and Cytokines via the $\mathrm{Nf}-\mathrm{Kb}$ pathway in Lps-Activated J774 Macrophage cells [58]. Loden 
and Andersson [57] also showed that Shea butter will reduce reaction to skin irritants. Hee [46] found $\alpha$-amyrin to be the most dominant triterpene in Shea butter's unsaponifiable fraction. Bioactivities of $\alpha$-amyrin have been studied especially with $\alpha$-amyrin extracted from Protium kleinii, a plant used in Brazillian folk medicine belonging to Burseraceae family. When administered, $\alpha$-amyrin was reported to show dose-related antinociceptive effect against the visceral pain when mixed with $\beta$-amyrin in vivo test on mice [59]. The topical application of $\alpha$-amyrin showed anti-inflammatory effects, inhibiting skin inflammatory responses such as edema formation, migration of polymorphonuclear leukocyte, and increase in tissue IL-1 $\beta$ levels [60]. In another study on the anti-inflammatory effect of $\alpha$-amyrin and $\beta$-amyrin of Protium heptaphyllum, the result showed they retarded acute inflammation in rat model of periodontitis [61].

Effect on Cholesterol metabolism: Shea butter has been reported to be used by a pharmaceutical company, BSP Pharma, to lower cholesterol levels [62]. Tholstrup and co workers [63] observed a reduction of total cholesterol and low density lipoprotein (LDL) by Shea butter administration and attributed the anti-hypercholesterolemic effect to the high stearic acid content of Shea butter. In a study with rats, Akinwale and co workers [64] reported a significant reduction in High density lipoprotein (HDL), Total Cholesterol and Low density lipoprotein (LDL) when rats were fed with Shea butter. The anti-hypercholesterolemic effect of Shea butter was ascribed to the presence of saponins in it by Akinwale and co workers [64]. Saponin which is present in the unsaponifiable fraction of Shea butter [34-36] has been reported by several authors to lower serum cholesterol by forming mixed micelles with cholesterol and bile acids in the intestine thereby inhibiting its absorption and increasing its excretion [65-69].

Allergy: Although, Shea nut is distantly related to Brazil nut [70] which cross-reacts with almond, hazelnut, walnut, and peanut [71], there are no reports of allergy reaction owing to the topical or oral use of Shea butter. Furthermore, Kanwaljit and co workers [29] reported that Shea butter contains no IgE-binding soluble proteins and reassures that Shea butter is safe for use even for individual with nut allergy. Conversely, Wiedner [72] found that pharmaceutical composition containing at least 5\% of Shea butter's triterpenes such as butyrospermol, lupeol, parkeol, germanicol, dammaradienol, 24-methylene-dammarenol, and $\alpha$, and $\beta$-amyrins effectively suppresses hypersensitivity reaction such as Immunoglobulin $\mathrm{E}(\mathrm{IgE})$-mediated allergic reactions and autoimmune reactions in mammals.

Effect on protein metabolism: In a study with rats, Malachi [73] observed a decrease in total protein concentrations of the hepatic and renal tissues as well as the serum following the administration of Shea butter based diet. The decrease was attributed to the presence of saponin, which have been reported reduce protein digestibility by the forming sparingly digestible saponin-protein complexes in the intestine [74,75]. Conversely, Belewu and Yahaya [76] reported that there was no digestive disturbance in feeding goats with Shea butter cake after observing a significant increase in crude protein digestibility in goats fed with Shea butter cake against control goats fed with soybeans cake. Furthermore, Akinwale and co worker [64] suggested that the decrease in serum albumin level following the feeding of rats with Shea butter based diet is as a result of utilization of Albumin in the transport of free fatty acids resulting from lipolysis in adipocytes.

\section{Conclusion}

In summary, there is enough evidence to substantiate the claims of the health benefits of the topical use of Shea butter. The dietary use of Shea butter, though has the advantage of anti-hypercholesterolemic actions, is suspected to interfere with protein digestion.

\section{References}

[1] Alfred T (2002) "Fats and Fatty Oils". Ullmann's Encyclopedia of Industrial Chemistry. Weinheim: Wiley- $\mathrm{VCH}$.

[2] Samuel H (2005) American Shea Butter Institute hand book, $11.28 \mathrm{http}: / /$ www.American_Shea institute.com/

[3] Ndukwe I G, Amupitan JO Isah Y, Adegoke K S (2007) Phytochemical screening of the crude extract of the roots, stem bark and leaves of Vitallaria paradoxa (GAERTN. F). African journal of Biotechnology, Vol 6, No 16, pp 1905-1909.

[4] El-Mahmood A M, Doughari J H, Ladan N (2008) Antimicrobial screening of stem bark extracts of Vitellaria paradoxa against some enteric pathogenic microorganisms. African Journal of Pharmacy and Pharmacology Vol. 2(5). pp. 089-094.

[5] Ferris R S B, Collinsom C, Wanda K, Jagwe J, Wright P (2001) Evaluating the Market Opportunities for Shea Nut and Shea Nut Processed Products in Uganda. Submitted to USAID, The United States Agency for International Development (available at http://www.foodnet.cgiar.org/Projects/Sheanut_Rep.pdf accessed on 13-8-2014)

[6] Di Vincenzo D, Maranz S, Serraiocco A, Vito R, Wiesman Z et al. (2005) Regional Variation in Shea Butter Lipid and Triterpene Composition in Four African Countries. J. Agric. Food Chem. 53: 7473-7479.

[7] Mbaiguinam M, Mbayhoudel K, Djekota C (2007) Physical and Chemical Characteristics of Fruits, Pulps, Kernels and Butter of Shea Butyrospermum parkii (Sapotaceae) from Mandoul, Southern Chad. Asian J. Biochem. 2:101-110.

[8] Pretaorius C J, Watt E (2001) Purification and Identification of Active components of Carpobrotusedullis L. J. Enthnopharma 76: 87-91.

[9] Agbahungba G, Depommier D (1989) World Oil Seeds Chemistry,Technology and Utilization. Van Nostraud Rein Hold, New York. p.554.

[10] Masters E T, Yidana J A, Lovett P N (2010) Reinforcing sound management through trade: Shea tree products in Africa. Trade and substainable forest management. http://www.fao.org/docrep/008/y5918e/y5918e11.htm (accessed on 13-8-2014). 
[11] National Research Council (2006) Lost Crops of Africa: Volume II: Vegetables. ISBN 978-0-309-10333-6.

[12] Soladoye M O, Orhiere S S, Ibimode B M (1989) Ethanobotanical Study of two Indigenous Multipurpose Plants in the Guinea Savanna of Kwara State - Vitellaria paradoxa and Parkia biglobosa. Biennial Conference of Ecological Society of Nigeria. Forestry Research Institute, Ibadan. p.13.

[13] Ferry MP, Gessain M, Geeain R (1974) Vegetative Propagation of Shea, Kola and Pentadesma. Cocoa research institute, Ghana Annual Report (1987/88): 98-100.

[14] Axtell B, Kocken E, Sandhu R (1993) Oil processing, United Nations Development Fund for Women (UNIFEM), Food Cycle technology Source Books. Intermediate Technology Public Ltd London.

[15] Kar A, Mital HC (1981) The Study of Shea Butter. VI: The Extraction of Shea Butter. Qual Plant Plant Foods Hum Nutr. 31: $67-69$

[16] Abbiw D K (1990) "Useful plants of Ghana, West Africa. Uses of wildand cultivated plants". Intermediate technology publication and the royal botanic gardens, Kew, London, pp. 66-67.

[17] Njoku O U, Eneh FU, Ononogbu IC, Adikwu MU (2000) Compositional and Toxicological Studies on Shea Butter. $J$ Nutraceut Function Med Foods (Currently J Diet Suppl.) 2: 33-39.

[18] Chalfin B (2004) Shea Butter Republic. Routledge. New York, NY. Intro, Ch. 1.

[19] Akihisa T, Kojima N, Katoh N, Ichimura Y, Suzuki H, Fukatsu et al. (2010) Triterpene alcohol and fatty acid composition of Shea nut from seven African countries. J Oleo Sci. 59(7): 351-360.

[20] Ogbonnaya C, Adgidizi P P (2008) Evaluation of some Physico-chemical properties of Shea butter (Butyrospermum paradoxum) related to its value for food and industrial utilization. International Journal of Post Harvest Technology and Innovation. 1(3). pp 320-326.

[21] Fold N (2000) "A matter of good taste? Quality and the construction of standards for chocolate in the European Union. Cahiersd'Economieet Sociologie Rurales, 55/56: 92-110.

[22] Tella A (1979) Preliminary Studies on Nasal Decongestant Activity from the Seed of Shea Butter Tree, Butyrospermum parkii. Br. J. clin. Pharmac. 7:495-497.

[23] Badifu G I O (1989) Lipid Composition of Nigerian Butyrospermum paradoxum Kernel. J Food Comp Anal. 2:238-244.

[24] Goreja WG (2004) Shea Butter: The Nourishing Properties of Africa's Best-Kept Natural Beauty. Amazing Herbs Press. New York, NY.

[25] Olaniyan A M, Oje K (2007) Quality Characteristics of Shea Butter Recovered from Shea Kernel through Dry Extraction Process. J. Food Sci Technol. 44: 404-407.

[26] Russo L, Etherington T (2001) Non wood news. An information bulletin on non-wood forest products 8:38-39.

[27] Fluery J M (1981) “The butter tree”. IDRC-reports, 10(2): 6-9.

[28] Essengue S B, Stechschulte D, Olson N (2009) The use of Shea butter as an Emollient for Eczema. Journal of Allergy and Clinical Immunology. 123(2). Pp 145-148.

[29] Kanwaljit K C, Ramon B, Rosalia A, Galina G, Anna N W (2010) Shea butter contains no IgE-binding soluble proteins. letter to the editor. J Allergy Clin Immunol . Volume 127, Issue 3, Pages 680-682. doi:10.1016/j.jaci.2010.10.022.

[30] United States Agency For International Development, (2006) "Buying and Selling Shea Butter: A Marketing Manual for West Africa".

[31] Booth F E M, Wickens G E (1988) "Non-timber uses of selected arid zone trees and shrubs in Africa". FAO-conservation-guide.

[32] Esuoso KO, Lutz H, Bayer E, Kutubuddin M (2000) Unsaponifiable Lipid Constituents of Some Underutilized Tropical Seed Oils. J. Agric. Food Chem. 48: 231-234.

[33] Maranz S, Wiesman Z (2004) Influence on the Tocopherol Content of Shea Butter. J. Agric. Food Chem. 52:2934-2937.

[34] Itoh T, Tamura T, Matsumoto T (1974) Sterols, Methylsterols, and Triterpene Alcohols in Three Theaceae and Some Other Vegetable Oils. Lipids. 9:173-184.

[35] Lipp M, Anklam E (1998) Review of Cocoa Butter and Alternative Fats for Use in Chocolate-Part A. Compositional Data. Food. Chem. 62: 73-97.

[36] Alander J (2004) Shea Butter- a Multi Functional Ingredient for Food and Cosmetics. Lipid Technol. 16:202-205.

[37] Peers K E (1977) The Non-Glyceride Saponifiables of Shea Butter. J Sci Fd Agric. 28:1000-1009.

[38] Hamilton R J, Rossell J B (1986) Analysis of Oils and Fats. Elsevier Applied Science. New York. NY. Ch. 1.

[39] Davrieux F, Allal F, Piombo G, Kelly B, Okulo J B et al. (2010) Near infrared spectroscopy of high- throughput characterization of Shea tree (Vitellaria paradoxa) nut fat profiles. Journal of Agricultural and food Chemistry, 58, 7811-7819.

[40] Nelson D L, Cox M M (2008) Lehninger. Principles of biochemistry. W. H. Freeman Publisher. 5th Ed. Chapter 10. Pp 346.

[41] Baydar N G, Özkan G, Cetin E S (2007) Characterization of Grape Seed and Pomace Oil Extracts. Grasas Aceites. 58:29-33.

[42] Damodaran S, Parkin KL, Fennema OR (2008) Fennema's Food Chemistry. 4th edn. CRC Press. Boca Raton, FL. Ch. 4.

[43] Samman S, Chow J W Y, Foster M J, Ahmad Z I, Phuyal J L et al. (2008) Fatty Acid Composition of Edible Oils Derived from Certified Organic and Conventional Agricultural Methods. Food Chem. 109: 670-674.

[44] Maranz S, Wiesman Z, Bisgaard J, Bianchi G (2004) Germplasm resources of Vitellaria paradoxa based of variations in fat composition across the species distribution range. Agroforestry systems (in cooperation with ICRAF). 60:71.

[45] Velasco M V R, Sarruf F D, Salgado-Santos I M N, Haroutiounian-Filho C A, Kaneko T M et al. (2008) Broad Spectrum Bioactive Sunscreen. Int J Pharm. 363: 50-57. 
[46] Hee S N (2011) Quality characteristics of West African Shea butter (Vitellaria paradoxa) and approaches to extend shelf-life. Masters of Science Thesis. Graduate School-New Brunswick Rutgers, The State University of New Jersey.

[47] Alander, J, Andersson, A C (2002) The Shea Butter Family the Complete Emollient Range for Skin Care Formulations. Cosmetics and Toiletries Manufacture Worldwide, 2002: 28-32.

[48] Kraft J N, Lynde C W (2005) Moisturizers: What They Are and a Practical Approach to Product Selection. Skin Therapy Letter. 10: $1-8$.

[49] Rogers S, O'Lenick Jr A (2009) Shea Butter Alkoxylates. United States Patent (US 7544824 B2). (available at: http://www.freepatentsonline.com/7544824.pdf, accessed on 13-8-2014)

[50] Hemat R A S (2003) Principles of Orthomolecularism. Urotext. p. 160. ISBN 9781903737057.

[51] Sheperd M (2012) Winter Itch. Sheperd Integrative Dermatology Notebook.

[52] Poelman M C, Richard A, Machado E (1988) Etude del'activité hydratante d'une émulsion essai de l'émulsion Xéroderm. Les Nouvelles dermatologiques, vol. 7, no1, pp. 78-79.

[53] Bird K (2009) Moisturising power of Shea butter highlighted by scientific studies. Cosmetics. Formulation \& Science. http://www.cosmeticsdesign-europe.com/Formulation-Science/ Moisturising-power-of-Shea-butter-highlighted-by-scientific-st udies. (Accessed on 12-8-2014).

[54] Belibi S E, Stechschulte D, Olson N (2009) The Use of Shea Butter as an Emollient for Eczema. Journal of Allergy and Clinical Immunology. Volume 123, Issue 2, Supplement, Page S41.

[55] Tran T (1986) Parfumes, Cosmétiques et Arômes, 58, 65-66.

[56] Renard R (1990) Le buerrede karate. Thése de Doctorat en Pharmacie. UFR de sciences pharnacuetiques. Universite de Bordeaux II, p 100.

[57] Loden M, Andersson A C (2008) Effect of topically applied lipids on surfactant-irritated skin. British Journal of Dermatology. Volume 134, Issue 2, pp 215-220.

[58] Nandini V Rina C Rakha H D, Hemant K G (2012) Anti-Inflammatory Effects of Shea Butter through Inhibition of Inos, Cox-2, and Cytokines via the Nf-Kb Pathway in Lps-Activated J774 Macrophage Cells. Journal of Complementary and Integrative Medicine. 9(1) pp 1-11.

[59] Otuki M F, Ferreira J, Lima F V, Meyre-Silva C, Malheiros A, et al. (2005a) Antinociceptive Properties of Mixture of $\alpha$-Amyrin and $\beta$-Amyrin Triterpenes: Evidence for Participation of Protein Kinase $\mathrm{C}$ and Protein Kinase A Pathway. J. Pharmacol. Exp. Ther. 313:310-318.

[60] Otuki M F, Lima F V, Malheiros A, Yunes R A, Calixto J B (2005b) Topical Anti-inflammatory Effects of the Ether Extract from Protium kleinii and $\alpha$-amyrin Pentacyclic Triterpene. Eur J Pharmacol. 507: 253-259.

[61] Holanda P S A, Pinto L M S, Cunha G M A, Chaves M H, Santos F A et al. (2008) Anti-inflammatory Effect of $\alpha$, $\beta$-Amyrin, a Pentacyclic Triterpene from Protium heptaphyllum in Rat Model of Acute Periodontitis. Inflammopharmacology. 16: 48-52.
[62] Masters E T, Yidana J A, Lovett P N (2004) Reinforcing Sound Management through Trade: Shea Tree Products in Africa. Unasylva. 210: 46-52.

[63] Tholstrup T, Marckmann P, Jespersen J, Sandström B (1994) Fat high in stearic acid favorably affects blood lipids and factor VII coagulant activity in comparison with fats high in palmitic acid or high in myristic and lauric acids. Am J Clin Nutr. vol. 59 no. 2. pp 371-377.

[64] Akinwale A, Modu S, Maisartu M A, Zainab M A, Bilkisu U M A (2012). Effect of Feeding Various Concentrations of Shea oil on Some Biochemical Parameters in Normal Albino Rat. Bulletin of Environment, Pharmacology \& Life Sciences Volume 1, Issue 2, 14 -17.

[65] Oakenfull D G, Sidhu G S (1990) Could saponins be useful treatment for hypercholesterolemia? European J Clinical Nutri. 44: $79-88$

[66] Sidhu G S, Oakenfull D G (2005) A mechanism for the hypercholesterolemic effect of saponins. $\mathrm{Br} . \mathrm{J} . \mathrm{Nutr}$. 55(3):643-649.

[67] Yuldasheva L N, Carvalho E B, Catanho T J, Krasilnikov O V (2005) Cholesterol-dependent haemolytic activity of Passiflora quadrangularis leaves. Braz. J. Med. Biol. Res., 38(7) 1061-1070.

[68] Matsuura M (2001) Saponins in garlic as modifiers of the risk of cardiovascular disease. J Nutri.131:1000S-1005S.

[69] Das T K, Banerjee D, Charkraborty D, Pakhira M C, Shrivastava B et al. (2012) Saponin: Role in animal system. Vet. World. 5(4):248-254.

[70] Anderberg A A, Rydin C, K€allersj€o M (2002) Phylogenetic relationships in the order Ericales s. 1.: analyses of molecular data from five genes from the plastid and mitochondrial genomes. Am J Bot. 89:677-87.

[71] Sharma G M, Roux K H, Sathe S K (2009) A sensitive and robust competitive enzymelinked immunosorbent assay for Brazil nut (Bertholletia excelsa L.) detection. J Agric Food Chem. 57:769-76.

[72] Wiedner M S (2008) Novel Composition Containing Extracts of Butyrospermum Parkii and the Use of Such a Composition for Preparing a Medicament or a Dietary Supplement for the Treatment or Prevention of Inflammation Hypersensitivity or Pain. United States Patent Application Publication (US 2008/0124413 A1). (available at: http://www.freepatentsonline.com/20080124413.pdf, accessed on 12-8-2014)

[73] Malachi O I (2013) Effect Shea butter based diet on lipid profile and marker enzymes of the liver and kidney. B.Sc. Thesis. Ekiti State University, Ado-Ekiti, Nigeria.

[74] Potter S M, Jimenez-Flores R, Pollack J, Lone $\mathrm{T}$ A, Berber-Jimenez MD (1993) Protein saponin interaction and its influence on blood lipids. JAgri Food Chem. 41: 1287-1291.

[75] George F, Zohar K, Harinder P S, Klaus B (2002) The biological action of saponins in animals systems: a review. British Journal of Nutrition. 88: 587-605.

[76] Belewu M A, Yahaya A A (2008) Effects of Aspergillus niger treated Shea butter cake based diets on nutrient intake and weight gain of Red Sokoto goat. Afr. J. Biotechnol. Vol. 7 (9), pp. 1357-1361. 